\title{
Student Demonstration: The Case Study of 2007 Demonstration in Dhaka University, Bangladesh
}

\author{
Sajib Bala \\ Assistant Professor, Department of International Relations, Jahangirnagar University, Dhaka, Bangladesh.
}

\begin{abstract}
The conflict between army men and students of Dhaka University held on 20 August 2007 in the playground of the Dhaka University gymnasium over a trivial issue, triggering off student's unrest. This demonstration later turned into violent leaving hundreds injured. The sudden outbreak of violence led the students to go on a violent rampage and demanding the immediate withdrawal of the army camp from the campus, which had been established in the country after the non-party caretaker government (NCG) assumed power. The NCG apologized to the students for the incident and decided to remove the army camp from the campus with immediate effects were pacifying steps in that direction. However, the cumulative anger amongst the students had spread far beyond the university campus. This led the caretaker government to impose curfew on 22 August 2007. After the imposition of curfew, security forces arrested many teachers and students. In the face of growing public demand and uprising, government released them finally. As political freedom had been under duress due to emergency, state-society relationships, therefore, became strained. Under such circumstances, 20 August student demonstration was the first instance which gave the message to the army that retrieving political freedom must be brought back to solving country's enormous political and socio-economic problems. With this context in perspective, this research probes the causes and implication of 20 August student demonstration.
\end{abstract}

Keywords: Dhaka University campus, Military, Non-party caretaker government, Political movements, State of emergency, Student demonstration.

\section{Introduction}

University campuses in Bangladesh have been breeding grounds for political movements, and students took recourse to violence has not been an unfamiliar occurrence in the past. Being the premier university, the Dhaka University has all along made a significant contribution to the emergence of Bangladesh as a sovereign state. Since the Pakistani rule, the genesis of all political movements (1952, 1966, 1969, and 1990) had been in the campus of the Dhaka University. Even the students of this university were catalysts for declaring independence in 1971. Bangladesh was familiar of being governed by military juntas twice since 1975. And from the very beginning of Pakistan colonial period, the military ruler made Dhaka University their primary target for attack, so did the military backed non-party caretaker government in 2007. A row between army men and students over watching a football match between the Departments of Public Administration and Mass Communication \& Journalism at the Dhaka University gymnasium playground on 20 August 2007 sparked primarily a countrywide student demonstration.

The demand for the withdrawal of army camp from all university campuses swiftly gained ground. And within hours the agitation had spread to other university campuses, turning it into a virtual battle ground between police forces and protesting students. The situation worsened further when several hundreds more from other colleges joined students' procession in a show of solidarity. The sudden escalation of demonstration led to the imposition of curfew and the government closed down universities and colleges in all metropolises, thus forced students to vacate Halls and hostels immediately on 22 August evening. Many teachers and students were arrested by the law enforcement agencies due to this incident. But in the face of growing public resentment, government was forced to release them. Against this backdrop the purpose of the research is to look into the causes of 20 August demonstration took place in the Dhaka University campus. With a view to answering the main question, this study aims to take the following objectives: To determine whether the demonstration was spontaneous or pre-planned. To find out any political interests behind this confrontation. To investigate why it happened under the state of emergency. To examine the pattern of civil-military relationships in Bangladesh. However, this article is divided into seven sections. With introduction in the first section, the second section justifies the research on the topic in the light of literature review. The third section discusses the background of the study with some lights on concepts. In the fourth section, a graphic description of the incident took place on 20 August has been made. The fifth section presents the data of both quantitative and qualitative. The analyses of data along with results and findings have been included in the sixth section. Finally, a conclusion has been drawn in section seven based on the discussion made throughout the paper. 


\section{Review of Related Literature}

There are few literatures available regarding students' demonstration. In this paper, I have organized my literature review in the form of Inverse Pyramid which starts from international perspective and gradually goes onto national perspective.

S. M. Lipset in the book "Students in Revolt"1 qouted, "Hobbes in his book 'Behemath' shows that in England from 1640-1660 there were many civil wars. Then he went on to find out causes and sources of the wars. Here, he overwhelmingly found that the universities of England were the breeding houses of movements and civil war."

M. Weiner in his book "The Politics of Scarcity"2 asserts that political parties adjoin students in demonstration to make the procession larger. Students become the most important workers of political parties. Opponent parties always try to put the government in trap or danger and then intensify their show. Weiner declares that the Indian political leaders have always tried to use the students to turn anti-government movement to mass revolution.

Talukder Maniruzzaman in his book "The Bangladesh Revolution and Its Aftermath"3 went on to indentify the historical origin of student politics and student movement in Bangladesh. He said that student politics in Bangladesh has always been very active and functional. Student political activism in the 1950s and 1960s was greater intensity, continuity, concern in Bangladesh than other countries. Student sentiment against Pakistan was galvanized during the state language movement of 1948 onwards. The intensity of student political activities that provided much of the dynamism for the Bangladesh liberation struggle resulted in part from the existence of student political organizations and long tradition of student politics.

Mohammed Hannan in his masterpiece work "History of the Student Movement in Bangladesh, Part II"4 (in Bengali) maintains that the university has been a focal point of an assertion of freedom in this part of the world has never been in doubt. Successive regimes in Pakistan understood this truth only too well, and for the very good reason that of all the institutions of higher learning in pre-1971 Pakistan, it was only Dhaka University which identified itself, gradually and surely, with the larger canvas of Bengali political aspirations. The first instance of defiance went out from the university, back in March 1948, when an arrogant Mohammad Ali Jinnah sought to have Urdu imposed on the country as the language of the state. It was only the beginning. In subsequent years, the university would come to acquire the role of a crusading spirit. It is interesting to think that almost the entire Bengali political set-up in the 1960s and, later, in the 1970s comprised the young men who as students had spearheaded various movements on the campus. For example, Sheikh Mujibur Rahman became the unquestioned leader of the Bengali nationalist uprising in East Pakistan, students in Dhaka University kept on being at the forefront of political activities in the country. So, women like Begum Motia Chowdhury who is a prominent minister of present government, became a popular name as a left student leader in the university in 1960s. One can discern a trend that Dhaka University has remained a breeding ground of future politicians of present-day Bangladesh.

Dr. M. Anwar Hossain in his book "Kathgorai Dhaka Bisshobiddaloi: Remand O Karagar Er Dinolipi" (in Bengali) writes that the army attack on the students of Dhaka University was very undesirable and it shows that the interim government wanted to stop the free voice of the country. Students all over the country protested this incident. It was spontaneous resistance which was a sign of solidarity among the students. From 20 to 22 August, the demonstration was acquiring strength and support from mass population. The teachers came out of the classroom and stood beside the students. He writes, the teachers as well as students were arrested. They had to face trial. They experienced torture in cantonment and other unknown places. All the students and teachers of Dhaka University planned programs. Through a non-violent, peaceful movement they forced the government to free the teachers and students. Finally, on 22 January government freed them. He wrote a diary on his jail days.

Dr. Harun-or-Rashid in his book "University of Dhaka: The August Incident Arrest Remand and the Prison Days" (in Bengali) maintains the trifling scuffle between army men and students led to government to impose curfew in six metropolitan cities. Security forces tormented general students, brought charge against thousands of unidentified students and arrested university teachers. The colleagues of his university, the media, senate members of USA, Commonwealth, Amnesty International, European Parliament, and above all the mass population pressured the government to make them free. He also kept a diary on the imprisoned days. This notebook contains the description of their punishment and torture in jail.

\section{Conceptualization of Student Demonstration and Background of the Dhaka University Demonstration}

Any kind of demonstration may be conceived as a form of political participation. It could be either orchestrated or abrupt. Even it could remain at times peaceful or violent. If orchestrated, the duration of demonstration could be longer. The aim of the demonstration may be to seek a solution of a problem on a short term or a long term basis. Political demonstration targets the government. It wants the government or any organ 
thereof to be more responsive to the demands of the people. In the human history, there are ample evidences that the youths have always spearheaded the struggle to protest against the repressive character of the state.

Student demonstration may be defined as a group of students, aware of their rights and obligations, united on a principle to advance national interests. Student demonstration or movements, designation given to the ideas and activities of student groups involved in social protest. Historically, student movements have been in existence almost as long as universities themselves. As early as the 4th century, students were engaged in protests against many unpopular political activities. Students played a crucial role in almost every one of the major revolutions of the 19th and 20th century. The coming of the modern era saw an increase in student activism. In what follows, I shall discuss about the nature of student demonstration that took place in the Dhaka University.

\subsection{Caretaker Government's Role}

Military backed non-party caretaker government took power on 11 January 2007. Though the ninth parliamentary election was supposed to hold on 22 January 2007, it did not happen in time. The controversy centered on the appointment of Chief Advisor of the caretaker government. A new chapter was added to Bangladesh's turbulent history on 1/11, as the event was popularly referred to Dr. Fakruddin Ahmed, renowned economist and former Bangladesh Bank Governor, was appointed as the Chief Advisor of caretaker government getting the support from military. The imposition of an emergency controlled the volatile political situation. But the CG faced the challenge of legitimacy when it went far beyond the mandate that had been assigned to it, with Chief Aadvisor reiterating his commitment to hold elections only before the end of 2008.

\subsection{Prolonged State of Emergency}

President Iajuddin Ahmed, with the backing of army declared a state of emergency on 11 January. With this declaration, political activities across the country went under suspension. The pending 22 January parliamentary elections were postponed. Though according to the Bangladesh constitution, government can keep a state of emergency for maximum four months, however, the emergency was extended till August commencing from January. This rule restricted public affairs, and banned political and social gathering. All the men as well as student were under pressure, and getting frustrated. This frustration spurred demonstration.

\subsection{Detaining the Chief Leaders of Two Popular Political Parties}

The government also attempted to neutralize the power of two major parties, AL and BNP, by declaring a policy commonly known as 'Minus Two Formula', which meant sending AL chief, Sheikh Hasina and BNP chief Khaleda Zia on exile. This move however failed when Khaleda refused to leave the country. Though Hasina had left the country, she managed to force her way back. The government, however, did not give up its determination to neutralise the two parties and ordered the arrest of Hasina and Khaleda in June and September 2007 respectively on charges of corruption. This arrest incited the supporters of these two parties.

\subsection{Partisan Politics}

National politics does make influence on campus politics in Bangladesh. Teachers of Dhaka University are also divided along the partisan line. There may have nexus between student demonstration and this type of partisan politics.

\subsection{Discontent among Lower Economic Class}

The checking of rickshaw licenses in the city annoyed many unlicensed or fake-licensed rickshaw pullers and owners. So there was resentment against the authority among them. The clearance of hawkers from pavements angered them as they could not do business as usual. The demolition of slums, although seen as an action against the poor, led to crime-free zones within the community depriving criminals from the slums. The poor slum dwellers were helpless, and could not say anything against them. All these above factors have been compounded by the high rise of the prices of essential commodities.

For all the above reasons, politics of the country was passing through turbulence. In this ready-made situation, student demonstration spearheaded the fall of the military backed caretaker government.

\section{20 August Demonstration and Aftermath}

The army set up a camp on 10 December 2006 at Dhaka University gymnasium. Since then the students were alleging that the army has been hogging the gymnasium depriving the students taking physical exercise. In these circumstances, a sudden outburst of fire ignited an unprecedented agitation caused by a ridiculous scuffle between certain students and army men at DU playground. The initial cause of the demonstration was an incident around 3.30 p.m. on 20 August 2007, when army personnel beat some DU students and humiliated a teacher over a petty dispute concerning comments passed by students watching a 
soccer match being held between the Departments of Public Administration and Mass Communication \& Journalism in the university gymnasium playground where an army camp was situated. ${ }^{7}$

In protest, students demonstrated against the army action, demanding an apology and removal of the army camp from the campus. In response, police baton charged the students injuring five or six of them. By early evening, news of the events had spread; triggering a few thousand more students to pour onto the streets in protest. $^{8}$ In a press conference in the campus on 21 August 2007, students claimed their five point demands. They were (1) Punishing the offender within twenty four hours. (2) Removing of army camp and police from all the educational institutions. (3) Bring back democratic environment in the country (4) Asserting that the demonstrators must not face any harassment and finally (5) Make free the entire arrested students. ${ }^{9}$

The Dhaka University Teachers Association (DUTA) in an emergency general meeting on 21 August demanded lifting of the state of emergency to pave the way for establishing democratic environment. The association also expressed solidarity with the demands of students. Following the brutalities inflicted on DU students on 20 August, along with the students of different universities across the country including Jahangirnagar University, Chittagong University and Rajshahi University burst into protest in the next day, bringing academic activities to an abrupt halt. Students of the universities and colleges expressed solidarity with the demands placed by DU students, boycotted classes as well.

In the face of violent protest by thousands of students and demand for withdrawal of the army camp, a high level meeting chaired by Chief Adviser (CA), Fakhruddin Ahmed at his office in the afternoon of 21 August took the decision of withdrawing the army camp from the campus. Meantime, the army person responsible for 20 August soccer match incident was withdrawn from the army camp on the DU campus next day, and an investigation against him begun. ${ }^{\mathbf{1 0}}$ On 22 August, amid escalating violence, the caretaker government imposed indefinite curfew in six divisional cities from 8:00 p.m. and shut down all universities in the country and colleges in the metropolitan cities sine die, asking students to vacate halls. Dhaka University (DU) residential students had to leave the dormitories by 8:00 p.m. before the curfew started. BBC reported that several citizens were also beaten up in different areas of the capital on suspicion of being students. Law enforcement agencies surrounded and raided the Aziz Supermarket at about 9:00 p.m. and went from door to door in search of students at apartments on top of the market. ${ }^{11}$

On 24 August, the joint forces hauled in Dhaka University Teachers Association (DUTA) General Secretary Professor Anwar Hossain and Social Science Dean Prof. Harun-or-Rashid at about 12:30 a.m. from their campus residences on the Fuller Road . ${ }^{12}$ In Rajshahi, Prof. Saidur Rahman Khan, Prof. Abdus Sobhan and Moloy Kumar Bhowmik were arrested. Later, the names of Dulal Chandra Biswas, Sayed Selim Reza Newton, and Abdullah Al Mamun were included among the condemned. On 16 September Prof. Sadrul Amin and on 17 September Prof. Neem Chandra Bhoumik, both DU academicians, surrendered to the court and the court sent them to jail. Around 84,000 unidentified students in 59 cases were accused of violating emergency power rule, attacking security forces and vandalizing public and private vehicles. ${ }^{13}$

A judicial probe commission was formed on 25 August 2007 to investigate the demonstration at the Dhaka University campus and was given 15 working days to submit its report. In the report it was said that the three-day student protest was initially spontaneous but later a vested quarter and some politicians instigated it. The one-member commission comprising Justice Habibur Rahman Khan submitted its report to the chief adviser on 15 November with a 28 -points recommendation to ensure a congenial academic atmosphere on the campus. ${ }^{14}$

The demonstrators demanded release of the detainees immediately for the sake of maintaining a congenial academic atmosphere in the university. After five months of imprisonment, four Dhaka University teachers were also released from prison on 22 January 2008 evening following a presidential mercy. In addition to the presidential pardons, the government also withdrew a number of cases against the teachers and students. Next day, the detained eight DU students were released in three phases.

\section{Data Presentation}

This research has been conducted by using a combination of both interview and case study method which is commonly defined as quantitative and qualitative method respectively. In my study, I have mainly focused on Dhaka University campus. In addition, I have included Jahangirnagar University and Rajshahi University campus too. The subjects of the study were the students and teachers of these universities who were mostly suffered from that incident. For this, the sample was drawn purposefully. For the convenient of this research I took a sample size of 15 students and 10 teachers. There were eight male and seven female students in my sample. In this study, I have used two well developed semi-structured questionnaires for data collection. One questionnaire was for the teachers and the other for the students. There were ten common questions in two sets of questionnaire. Both of the questionnaires had open ended and close ended questions. For an intensive study, I have incorporated case studies. 
Student Demonstration: The Case Study of 2007 Demonstration in Dhaka University, Bangladesh

5.1 Results of Interviews

Table 1: Teachers' and students' perception to the demonstration (in percentage)

\begin{tabular}{|c|c|c|c|}
\hline $\begin{array}{c}\text { Sudden explosion of student demonstration } \\
\text { at the night of } 20 \text { August } 2007\end{array}$ & $\begin{array}{c}\text { Students' spontaneous } \\
\text { participation }\end{array}$ & \multicolumn{2}{|c|}{ Silently fueled by political parties } \\
\hline Teacher & 100 & \multicolumn{2}{|c|}{0} \\
\hline Student & 100 & \multicolumn{2}{|c|}{0} \\
\hline $\begin{array}{c}\text { Reasons behind the spread of } \\
\text { demonstration after the declaration of } \\
\text { removing army camp }\end{array}$ & Anti-army sentiment & Political motivation & $\begin{array}{l}\text { Dissatisfaction with } \\
\text { CG }\end{array}$ \\
\hline Teacher & 30 & 40 & 30 \\
\hline Student & 10 & 60 & 30 \\
\hline Factors responsible for demonstration & Normal reaction of students & \multicolumn{2}{|c|}{ From August 21, manipulated by others } \\
\hline Teacher & 80 & \multicolumn{2}{|c|}{20} \\
\hline Student & 35 & \multicolumn{2}{|c|}{65} \\
\hline Manipulation of the demonstration & Teachers & Political leaders & Others \\
\hline Teacher & 0 & 100 & 0 \\
\hline Student & 10 & 90 & 0 \\
\hline Spreading the way of demonstration & Instinct solidarity of students & $\begin{array}{l}\text { Motivation by } \\
\text { others }\end{array}$ & Both \\
\hline Teacher & 50 & 30 & 20 \\
\hline Student & 30 & 60 & 10 \\
\hline $\begin{array}{c}\text { Causes of joining the hawkers and } \\
\text { rickshaw pullers }\end{array}$ & Exchange of money & \multicolumn{2}{|c|}{ Expression of anger against $\mathrm{CG}$} \\
\hline Teacher & 10 & \multicolumn{2}{|c|}{90} \\
\hline Student & 25 & \multicolumn{2}{|c|}{75} \\
\hline Foreign link & Yes & \multicolumn{2}{|c|}{ No } \\
\hline Teacher & 0 & \multicolumn{2}{|c|}{100} \\
\hline Student & 0 & \multicolumn{2}{|c|}{100} \\
\hline $\begin{array}{l}\text { Respondents' support to army's } \\
\text { involvement in civilian affairs }\end{array}$ & Yes & \multicolumn{2}{|c|}{ No } \\
\hline Teacher & 20 & \multicolumn{2}{|c|}{80} \\
\hline Student & 15 & \multicolumn{2}{|c|}{85} \\
\hline Feeling of insecurity & Yes & \multicolumn{2}{|c|}{ No } \\
\hline Teacher & 100 & \multicolumn{2}{|c|}{0} \\
\hline Student & 100 & \multicolumn{2}{|c|}{0} \\
\hline Evaluation of CG & Positive governance & $\begin{array}{l}\text { Military backed and } \\
\text { corrupted governmen }\end{array}$ & Authoritarian \\
\hline Teacher & 30 & 70 & 0 \\
\hline Student & 20 & 50 & 30 \\
\hline
\end{tabular}

The table shows that all of the respondents both teachers and students think that the demonstration of 20 August was spontaneous, and students participated it at their own spirit. There was no political provocation at the dawn of the demonstration at playground.

$60 \%$ students and $40 \%$ teachers think that the demonstration of 21 August was motivated by political leaders for their interest. $30 \%$ Teachers and students, each opined that the demonstration went further because of student dissatisfaction with the rule of caretaker government. However, though $30 \%$ teachers maintained that the further demonstration may be the result of students anti army sentiment, only $10 \%$ students buy off this view.

Remarkably, $80 \%$ teachers opined that the demonstration of 21 August was a normal reaction of the students. But majority (65\%) students think that from 21 August the demonstration began to be manipulated by others. Only $20 \%$ teachers said that the demonstration was being manipulated. $35 \%$ students considered the second day demonstration as a normal reaction.

The table shows that a remarkable number of $65 \%$ students but only $20 \%$ teachers said the demonstration was manipulated. Among the teachers and students who think the demonstration was manipulated, $100 \%$ of teachers and $90 \%$ of students said that it was manipulated by political leaders. However $10 \%$ students made the teachers responsible for this. It is seen that nobody named or identified any other factors except these two.

We see that the majority teachers $(50 \%)$ responded that instinct solidarity of the students helped the demonstration to spread countrywide. On the other hand, $60 \%$ students think some other factors motivated the incident later. $20 \%$ teachers and $10 \%$ students respectively opined that both the solidarity and other factors.

Most of the teachers and students think that non-students mainly Hawkers and Rickshaw pullers joined the violence and sabotage to express their anger against the then caretaker government. However $25 \%$ students 
and $10 \%$ teachers think there might have any economic factors. Majority respondents discarded the view that there was money transaction involvement in that demonstration.

All of the respondents said that there was no foreign linkage with that demonstration. Many assumed that there may have any foreign linkage. But this research found no evidence in favor of this claim.

Significant number of respondents $(80 \%$ teachers and $85 \%$ students) does not support the involvement of army in civilian affairs. Interestingly, $20 \%$ teachers and $15 \%$ students have supported this involvement.

This table presents the panic situation that was existing in that time. All the respondents, teachers and students as well as their family were scared and felt unsecured.

Majority, 50\% students and $70 \%$ teachers have said that the then caretaker government was military backed and corrupted. Significant 30\% teachers and 20\% students maintained that was positive governance. $30 \%$ students called it an authoritarian regime.

Table 2: Teachers' perception to the demonstration

\begin{tabular}{|c|c|c|c|}
\hline Perception about imposing curfew & Avoid clash between students and police & $\begin{array}{l}\text { Create a dreadful } \\
\text { situation }\end{array}$ & Both \\
\hline Percentage & 30 & 40 & 30 \\
\hline $\begin{array}{l}\text { Modification of University Regulation } \\
\text { Act }\end{array}$ & Need some modification & \multicolumn{2}{|c|}{ No modification needed } \\
\hline Percentage & 60 & \multicolumn{2}{|l|}{40} \\
\hline $\begin{array}{l}\text { Evaluation on partisan politics in } \\
\text { university }\end{array}$ & $\begin{array}{l}\text { Should not involve in too much partisan } \\
\text { politics }\end{array}$ & \multicolumn{2}{|c|}{ It is good and supportable } \\
\hline Percentage & 70 & \multicolumn{2}{|l|}{30} \\
\hline
\end{tabular}

Majority (40\%) teachers said that CG suddenly imposed curfew to create a dreadful situation and took advantage of this situation. 30\% teachers thought that government imposed curfew to avoid further clash between students and police. Another $30 \%$ respondents claimed both.

Most of the teachers (60\%) thought that University Regulation Act needs revision or modification. $40 \%$ teachers did not support any modification.

This table shows that almost all the teachers (70\%) do not support the existing partisan students' and teachers' politics. The rest $30 \%$ teachers support students' and teachers' politics in university.

Table 3: Students' perception to the demonstration

\begin{tabular}{|l|l|l|l|}
\hline Source of motivation & Self motivation & Motivated by political force \\
\hline Percentage & 90 & 10 \\
\hline $\begin{array}{l}\text { Difficulties faced by students while going back } \\
\text { home }\end{array}$ & Lack of transport & $\begin{array}{l}\text { Constraints of communication } \\
\text { with family and friends }\end{array}$ & $\begin{array}{l}\text { Both } \\
\text { Percentage }\end{array}$ \\
\hline Percentage of torture or humiliation & 10 & 10 & No \\
\hline Percentage & Yes & 70 \\
\hline
\end{tabular}

Most of the students were self motivated. Most of the students, who were of the university, joined the demonstration at their own will. However it shows the sign of political involvement in the demonstration. $10 \%$ students are reported to have been influenced by political force.

The table shows that almost all of the students, who were forced to leave Dhaka after imposing curfew, faced various difficulties on roads. They could not avail transports and communicate with one another as the networks of mobile phones were shut. They did not get enough time to pack their luggage.

The table presents that some of the students $(30 \%)$ were humiliated or tortured on roads by police or other security forces. However, majority $70 \%$ did not face such problems.

\subsection{Case Studies}

For further understanding of the situation, I have also used case study method. Under this method, I have studied the opinions of Mr. Aka Firowz Ahmad, Mr. Dulal Chandra Biswas, Mr. Mahbubul Mokaddem Akash (M.M. Akash), and Mr. Manobendro Dev.

\subsubsection{Mr. Aka Firowz Ahmad}

Aka Firowz Ahmad was a professor of Department of Public Administration of Dhaka University. In August 2007, he was the proctor of the university. As a proctor, he played the vital role during that time of incident. According to him, there were several causes of that student demonstration. There had been some simmering discontent among different sections of people and students regarding different issues. Students and political parties were frustrated. However, this frustration produced anger. According to professor Firowz, the

Nature of that demonstration was like a mass upsurge and there might be the chance of political patronage. To him, the countrywide violence was not the direct consequence of 20 August incident. The incident at playground was undesirable for him but he admits the response of the students was spontaneous in the initial 
stage. He maintains that there was continuous dialogue between Dhaka University administration and government official after the incident. Through a long negotiation, Dhaka University administration persuaded the government to remove the army camp from the campus. However, he does not reject the possibility of involvement of teachers' politics. Aka Firowz in most cases does not comply with the report of Habibur Rahman Khan Commission.

\subsubsection{Mr. Dulal Chandra Biswas}

At the time of the great 'August Incident' in 2007, Dulal Chandra Biswas was associate professor in the Department of Mass Communication of Rajshahi University. His involvement in organizing and participating in the silent procession on 21 August in Rajshahi University campus to protest army atrocity over the teachers and students of Dhaka University on 20 August finally sent him to jail. He asserts that like the University of Dhaka, Rajshahi University has played a major role in all democratic movements in Bangladesh.

Defending the causes of turning trifling scuffle into a countrywide clash, Dulal Chandra Biswas think that people of Bangladesh were fed up with the then rule of caretaker government. To him, though it was apparently a civilian government, it was in fact a military backed rule. The government had prohibited political activities, proclaimed state of emergency rule, banned indoor politics and arrested many political leader. Civil society was hardly active. Leading print and electronic media became their handmaid. These were accompanied by price hike. So the mass people of the country became frustrated and skeptic of caretaker government though in the earlier period they supported it. The military interfered in many civilian affairs of politics and economy. The interim government got involved in many affairs which was actually out of their term of references. People were looking for a chance to express their anger against the caretaker government. All these ignited the sudden outburst of indignation.

\subsubsection{Mr. M M Akash}

Dr. Mahbubul Mokaddem Akash was a professor of Department of Economics of Dhaka University. He said that there was an anti-army sentiment within the students of Bangladesh. He also thinks that the incident of 20 August at gymnasium was undoubtedly spontaneous. Prof. Akash suspects that later on that night the demonstration might have been manipulated by various political parties. He does not admit that there was any foreign linkage. However, he reminds that the demonstration was not fully motivated by political parties or others. It was largely spontaneous. Among the students, a sense of humiliation also worked. He maintains that many lower economic classes like Rickshaw pullers and Hawkers joined to express their anger as the government had eradicated the Hawkers and banned Rickshaw on VIP roads. He states that sudden imposing of curfew was beyond his thinking. He looks upon the caretaker government as an 'ambitious circle aiming beyond their capacity'. He thinks, to join political party or support a definite political idea is a legal right both for teachers and students. But it should not hamper academic progress. So, he thinks, there need some modification in University Regulation Act 1973 to make it fully democratic, but not the way as suggested by Habibur Rahman Khan Commission.

\subsubsection{Mr. Manobendro Dev}

At the time of demonstration in August 2007, Manobendro Dev was president of Chhatra Union of Dhaka University unit. He was a student of International Relations at Dhaka University. From the playground he went to DMCH to see Mehadi, whom the army men beat up. Mehadi told him that the army men had scolded the students and they had protested it only. Manobendro says, students had been in hall under the state of emergency since January. On 21August he presided over a gathering on Madhu's Canteen. There, in a press briefing, after a short dialogue among the students, he pressed five point demands including removing army camp immediately from all educational institutions, and ensuring democratic environment in the country. $\mathrm{He}$ thinks that the use of unduly power to suppress students made students furious and violent. He opined that the university administration did not properly manage to reach a peaceful solution.

\section{Discussion of the Results and Findings}

The August student demonstration raised a lot of questions about the probable causes of demonstration, political involvement, authoritarian rule of caretaker government, any foreign connection, the real intention of military backed CG, the CG's view toward universities and above all the simmering dissatisfaction of different sections of people. From both the interview \& case study, it has been clear that the initiation of the incident was spontaneous and there were no political provocation, no foreign linkage. Both the teachers and students asserted that it was neither pre-planned nor provoked. The data shows some sign of the involvement of political forces. Habibur Rahman Khan Commission has also expressed this view saying 'student protest was initially spontaneous but later a vested quarter and some politicians instigated it'. This study also finds some students were forced to join in demonstration on 21 August. But the number of students forced to do it was not very 
large. However, there was a claim that the attempt of political leaders to manipulate the incident and take interest out of it. Some also make the teachers responsible for further rise up. There was an accusation being aired at that time that huge amount of money exchange in that demonstration. Many non students joined the violence in exchange of money. But this study finds no probe in favor of this accusation. In the wake of the Fakruddin's government it earned huge support but day by day it was losing its popularity. At that time, army got involved in many civilian affairs. This study shows that most of the teachers and students do not support this illegal involvement. They called it an authoritarian regime. There was an overwhelming matter that all the respondents were scared of being arrested or tortured by security forces. Many claimed that the caretaker government was corrupted and a puppet of army. Judicial Probe Commission reported that the University Regulation Act gives the teacher excess power and teachers are misusing this. Teachers were made stakeholders of politics and were divided along the 'color' which has been spawned by the much touted 1973 act with the provision of election to various university organs meant for academic administration. The commissioner opined that this act should be revised. Interestingly, only a few teachers do not agree to this point of the report, a large portion thinks the act needs some modification. Also a remarkable number of teachers do not support existing type of campus politics. Some of the respondents expressed grave concern about too much partisan student or teacher politics. The teachers presume that most of the students have little political motivation and function as medieval warlords with loyalties to their paymasters who need them to assert their political authority. Respondents' opined that politics should not hamper academic progress. However, none of the teachers favored the ban of student or teacher politics.

I have accumulated the findings of my study in a nutshell. All of the respondents agreeably believe that the incident was unexpected and the participation of whom was spontaneous at the initiation. Most of the respondents were unhappy with the rule of the then caretaker government. The students who were directly involved with sabotage were scared of being arrested. Teachers largely did not accept the report of Habibur Rahman Khan Commission. National level politics might have influenced the incident later, but it is not proven. There are enough supporters in favor of some modifications of the University Regulation Act of 1973.

\section{Conclusion}

In this research, the multiple causes of 20 August demonstration have been corroborated by collating evidence. The August 2007 student demonstration in Dhaka University campus reveals two forms of power configurations that manifested in state-society relations. On the one hand, it was the army possessing the coercive power backed by the state; it was the civil society which possessed the power of resistance on the other. With the support of political society, civil society strongly faced the coercive power of the armed forces. Finally, the army had to bow down to this resistance, promising to return to the barrack. The army felt their distance from the people. Consequently, army's return to the barrack allowed the 'non-party caretaker government' to help successful transition of democracy in Bangladesh. The 20 August demonstration in Dhaka University campus is surely a form of political participation, with far-reaching implications in the society which can never be underestimated nor can be ignored. This incident has set a permanent memory in the minds of students, teachers and well wishers of Dhaka University as well as the common people of the country and the government. But it reveals that, this incident made a significant contribution to forcing of military withdrawal from politics.

\section{References}

[1] S. M. Lipset, Students in Revolt (Boston: Beacon Press, 1970).

[2] M. Weiner, The Politics of Scarcity (Chicago: Chicago University Press, 1962).

[3] T. Maniruzzaman, The Bangladesh Revolution and Its Aftermath (Dhaka: The University Press Limited, 1980).

[4] M. Hannan, History of the Student Movement in Bangladesh: Part II (in Bengali) (Dhaka: Agamee Prakashani, 1994).

[5] M. Anwar Hossain, Kathgorai Dhaka Bisshobiddaloi: Remand O Karagar Er Dinolipi (in Bengali) (Dhaka : Agamee Prokashoni, 2008).

[6] Harun-or-Rashid, University of Dhaka: The August Incident Arrest Remand and the Prison Days (in Bengali) (Dhaka: Ananya Prokashani, 2008).

[7] M. Anwar Hossain, op. cit., p.9.

[8] Harun-or-Rashid, op. cit., p.14.

[9] The Daily Prothom Alo, Dhaka, 22 August 2007.

[10] Ibid.

[11] BBC Bangla News, 24 August 2007.

[12] M. Anwar Hossain, op. cit., p.17.

[13] The Daily Star, Dhaka, 23 January 2008, available online at http://www.thedailystar.net/archive.php?date=2008-01-23

[14] The Daily Star, Dhaka, 16 November 2007, available online at http://www.thedailystar.net/archive.php?date=2007-11-16. 